\title{
PRIMARY SCHOOL TEACHERS' TENDENCY TO BECOME A MANAGER: SAMPLE OF GAZIANTEP PROVINCE1
}

\author{
Cevdet Çetin ${ }^{1}$, Filiz Gölpek ${ }^{2}$, Zeynep Köse ${ }^{3}$, Muzaffer Mavigök ${ }^{4}$ \\ ${ }^{1}$ Assistant Professor Dr, Faculty of Education, Hasan Kalyoncu University, \\ Gaziantep/Turkey \\ ${ }^{2}$ Assistant Professor Dr, Faculty of Economic and Administrative Sciences, Hasan Kalyoncu University, \\ Gaziantep/Turkey \\ ${ }^{3}$ Instructor, Faculty of Economic and Administrative Sciences, Hasan Kalyoncu University, \\ Gaziantep/Turkey \\ ${ }^{4}$ Deputy Principal at Umut Primary School, \\ Gaziantep/Turkey
} ABSTRACT

Education has been a crucial process which has a significant role in the lifetime of individuals and societies since the ancient times and considered to be the system which enables economic, political and social system to be sustained. The fact that education system is important in terms of both education and economy necessitates large-scale investments and availability of substantive financial resources for education service to be provided. This imperative requires efficient management of primary schools in many countries in which public funding of education is at present. Efficient management of primary schools depends on school principals. In certain countries, principal may be someone out of school although in other countries as Turkey, teachers may become principals. To what extend can principals help the school, teachers, students and their environment? Analyzing the primary school teachers' tendency to become principal is of vital importance in terms of contributing the possible studies which will be conducted. Main purpose of this study is to determine whether or not primary school teachers' tendency to become a principal varies according to gender, age, graduation grade and period of service. In the study, a survey was conducted to 486 primary school teachers who worked in Gaziantep in 2012-2013 school year under general survey model. In consequence of the study, it is observed that personal tendency to become a manager changes by gender.

Keywords: Administration in primary schools, primary school teachers' tendency to become a manager,

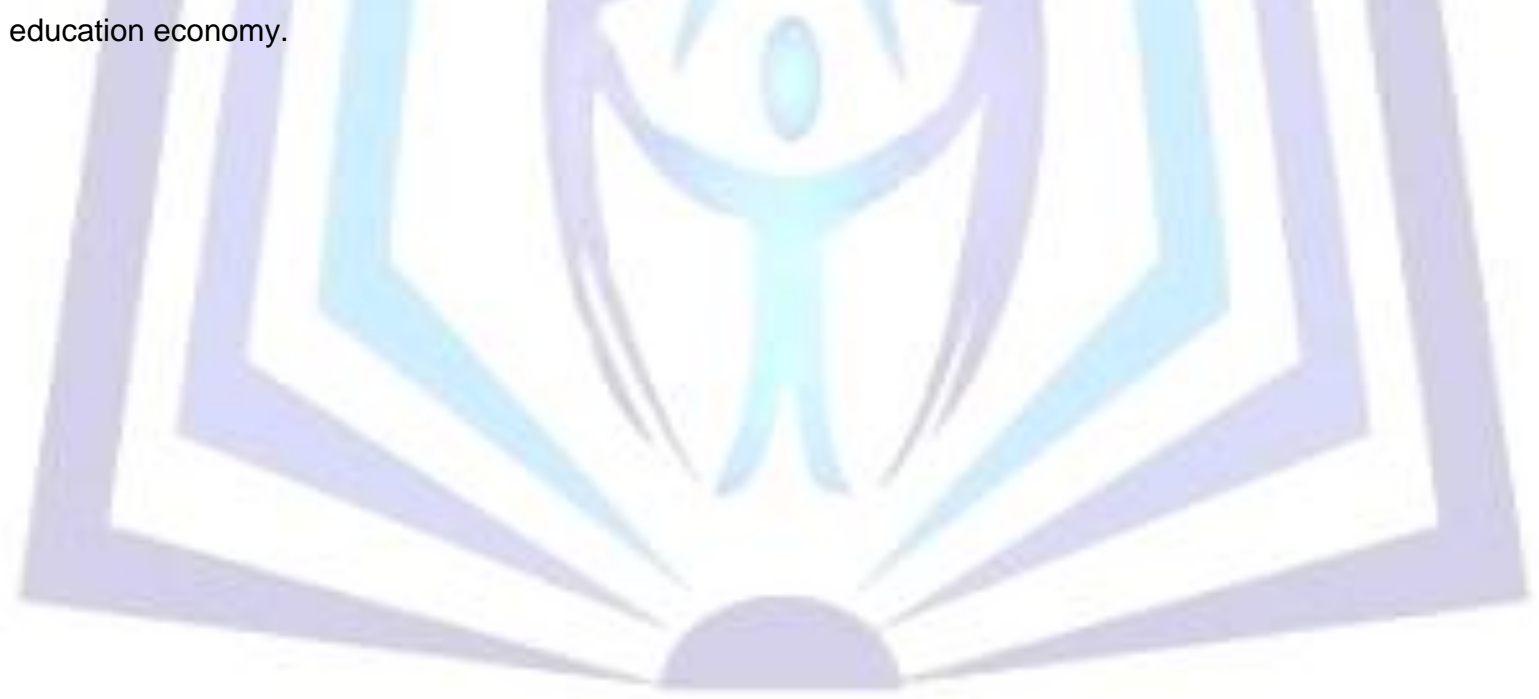

\section{Council for Innovative Research}

Peer Review Research Publishing System

JOURNAL OF SOCIAL SCIENCE RESEARCH

Vol 4, No 2

jssreditor.cir@gmail.com

www.cirworld.com 


\section{INTRODUCTION}

Education has been a crucial process which has a significant role in the lifetime of individuals and societies since the ancient times and considered to be the system which enables economic, political and social system to be sustained. From this point of view, education is defined as the process of systematic activities by which educators provide individuals with certain improvements in terms of behavior, abilities, character and knowledge (Balcı, 2010: 48). On the other hand, economists define education as a strong process which increases individuals' earning capacity and supports economic growth (Gölpek, 2011: 149).

The demand for education has been rising due to recent technological progresses, increased standard of living, and elevated population and schooling rate. To meet such an increased demand, it is essential to produce world class education services and to make huge physical capital as well as highly-qualified human capital investments. In this sense, providing educational institutions with source of financing that is necessary for large-scale investments, generating permanent financial resources that would enable them to function properly, and ensuring effective school management al become highly important. Notably in developing countries such as Turkey where resources are scarce and the process of economic growth must be accelerated, effective use of the resources allocated to educational institutions takes on a new significance (Aslan, 2011: 125).

Effective use of resources is extremely important in the case of both advanced and developing countries where almost all of primary school related expenditures are funded by public resources. For instance, according to average value of OECD countries for the year $2010,92 \%$ of primary and secondary education expenditures were funded by public resources (OECD, 2013). In Turkey, significant part of total government-origin expenditures in 2012 (" 51.912 .982 .190$)$ was spent for primary education (" 39.169.379.190) (Ministry of National Education, 2013).

However, public finance policy at primary education level is predicated on certain basic justifications. These justifications include guaranteeing that children within a certain age group receive basic and uniform education and ensuring that social rate of return at primary education level (13\%) is in excess of the rates at other levels (secondary education $9 \%$, higher education 8\%) (Gölpek, 2012: 1219; OECD, 2013).

Nevertheless, these justifications cause countries to allocate significant amount of resource to education and to face severe problems in terms of sourcing. This makes well and effective management of educational institutions, notably primary schools, obligatory.

Educational institutions are the places of service production where education is realized and knowledge is generated, protected and supplied to those who demand. The system of education in which educational institutions are incorporated, can be divided into two modes of education: formal education and non-formal education. In primary schools, which are classified under formal educational institutions and referred to as the first stage of education, managers represent an important factor as they have a direct effect on the quality of education and the public resources allocated. For these reasons, primary school management is regarded as a profession requiring specialization (Gölpek, 2013: 154; Ministry of National Education, 2013).

Yet, primary school management is not accepted as a profession, rather it is assigned to teachers as a secondary task. According to recent amendments to applicable legislation, managers shall take office under four-year assignment, and those who fail to display adequate performance by the end of this period shall be discharged. Considering these new regulations, primary school teachers' desire to become manager has become an important issue to be investigated. Considering very limited number of studies in this research area, this issue becomes much more important.

Within this framework, the objective of this study is to analyze primary school teachers' tendency by taking into account their personal and general characteristics. This paper consists of four sections including introduction and conclusion. Second section is dedicated to relevant theoretical background and findings obtained from limited number of studies conducted in this research area. Third section presents the data gathered from the survey carried out in the scope of this study in company with statistical analysis of the same. The last section, conclusion indicates the primary finding of this study; i.e., personal tendency to become a manager changes by gender.

\section{THEORETICAL FRAMEWORK AND LITERATURE REVIEW}

Management is the process of attaining organizational goals by using materials, human capital and physical sources on the basis of the principle of cooperation. In this process, management also acts a science, saving the organization from being classical, making it adapt itself to current conditions and requirements, and interacting with a great variety of external factors and innovations in order to derive and spread out benefits. One of the fields that both takes advantage of and supports management science is educational management.

Educational management deals with the realization of policies, decisions and objectives regarding the field of education. In doing so, it relates human resources to physical resources within management process (Keskinkılıç, 2011: 7). The most important one among these resources is the organizations called school (Bursalıoğlu, 2011: 6).

School is defined as the establishment which provides education and learning opportunities for everyone, on an equal basis and in all parts of a country, subject to the principles of social justice and equality of opportunity in education (Şişman, 2011: 1). What is expected from schools is achievement of aforesaid learning process in an effective manner. Before anyone else, school management is in charge of and responsible for achievement of effective learning.

In order to ensure effective learning, school management aims to make specific objectives and policies of a school come true, takes charge of proper maintenance of the school in keeping with its objectives and policies, focuses on 
implementation of the general concepts and processes of educational management at school level, and organizes, coordinates and directs human and physical resources with a view to attaining the school's specific objectives and policies (Balcı, 2010: 151; Bursalıoğlu, 2011: 5).

Also, it is only school manager who can take advantage of and optimize human and physical resources available at a given school (Taymaz, 2011:55). School managers are those who organize staff members in parallel with objectives, give directions, direct, coordinate and supervise all efforts at the school. The said managerial staff consists of principal, viceprinciples, group leaders, branch chairpersons, department heads and other coordinators to whom specific tasks are assigned. The purpose of every school manager is to keep schools alive in accordance with ministerial education policies and objectives and to maintain it as a well-functioning organization (Erdoğan, 2010: 128; Gürsel, 2003: 91).

School manager must allocate the large part of his/her office hours to the issues related with education and teaching, and be able to affect students' success whether directly or indirectly. School managers play a direct role with their position of being a source of teaching and a teacher; moreover, they indirectly affect the outputs of the school by some means or other, whether positively or negatively, with their decision-making power and significant influence over other people and inschool processes. In this case, school managers are expected to act as a leader, rather than a manager, particularly to lead the management of curriculum as well as teaching and learning processes, and to play the role of a head teacher in the eyes of teachers and students (Şişman, 2011: 139).

There is very limited number of studies that analyze primary school teachers' tendency to become manager. These studies put forward that teachers spend most of their time at school, which is mostly dedicated to the issues relating to teaching and improvement of teaching goals.

For instance, the study entitled Primary school teachers' tendency to become manager: Sample of Malatya Province conducted by M.B. Aksu (2004) indicates that as the participants' period of service in the profession gets longer, the average of their general desire to become manager tends to increase. According to the results of this study, female teachers' desire to become school manager does not differ significantly against education level and age variables while there is significant difference by professional seniority. This finding provides evidence for the hypothesis that female teachers who are in earlier times of their period of service are more willing to become school manager.

The study of M.Çelikten (2004) entitled Females sitting on principal's seat: Sample of Kayseri province establishes that female principals are not very happy with their position due to lack of self-confidence, not being supported by surrounding people, and having difficulty to make choice in face of the dilemmas such as work-family.

The study entitled Women's participation to working life and manageress models by G.Narman (2004) comes to the following conclusion: In general, women fail to go beyond the task seen fit by the society and their own organization. Women's capacity and level of education usually fall short of breaking down these prejudices. A woman holds the position of a person who helps her male work-fellow or whose managerial skills are expelled.

Investigating the prejudices and other factors that prevent female teachers from becoming manager conducted by N.Şimşek (2010) identifies certain prejudices that managerial positions would not be relinquished to young female teachers and a young manager could not be a favorable one due to the fact that there are more experienced teachers in the same environment.

The study entitled Primary school teachers' tendencies towards being administrator: Esenyurt Sample, performed by M. Bingül and Ö. Hacıfazlıoğlu (2011), obtained some data concerning personal tendencies in relation to teachers' desire to become manager. According to this data, both men and women have very low level of desire to become manager; however women's tendency is stronger than that of men.

In short, previous studies in this research area manifest that female teachers are not willing to become manager due to demographic characteristics, and that tendency to become a manager in primary schools changes by region, school and surroundings.

\section{METHOD}

\subsection{Model of the Study}

In order to determine primary school teachers' tendency towards being manager, general survey model has been was employed in this study. General survey model consists of survey arrangements performed on the entire universe or a subset of the universe in order to reach a general judgment about the universe, which is formed by a great number of components (Karasar, 1994: 79). This model focuses on capturing the characteristics of events and relationship between the events and the surrounding conditions instead of dwelling upon the reasons of events (Kaptan, 1995: 59).

\subsection{Universe and Sample}

The universe of the study is formed by primary school teachers working in the province of Gaziantep. According to the data furnished by Provincial Directorate of National Education, in 2012-2013 school year 4.696 teachers worked in public primary schools. In qualitative researches, selected sample size must reflect and represent the universe to the greatest extent possible. Sample selection was carried out by simple random sampling method. In this method, every unit of the universe has the equal chance of being selected as an independent unit. The required number of samples for a universe consisting of 5000 units is 356 at 95\% confidence level (Balcı, 2009: 92). In this study, the number of samples was considered to be 486 so as to fulfill the required confidence level. 


\subsection{Means of Data Collection and the Data}

In the study, Scale for Primary School Teachers' Tendency to be Manager developed by Aksu (2004) was used, and the data was obtained by means of survey. Survey consists of two parts: First part incorporates personal characteristics of 486 participants; i.e., gender, age, graduation grade and period of service (Table 1). Second part comprises 20 questions devoted to general tendency and personal tendency sub-dimensions in order to specify the sample group's tendency to become manager (Table 2, Table 3). For these questions, Likert scale was used as it allows to arrange teachers' responses in the form of a scale-based level identification chart. Level identifications are marked from 1 to 5 with the following meanings; I exactly agree $=(5)$, I agree $=(4)$, I am indecisive $=(3)$, I do not agree $=(2)$, I strongly disagree $=(1)$. $\mathrm{t}$ test, $\mathrm{F}$ test, $\mathrm{X}^{2}$ test, analysis of variance and Kruskal Wallis-H test were conducted on SPSS software. All data obtained were tabulated as well.

In the light of this information, frequency and percentage distributions of personal characteristics were calculated. Results of calculations are indicated in Table 1.

Table 1. Frequency and percentage values as to Teachers' Gender, Age, Graduation Grade and Period of Service

\begin{tabular}{|c|c|c|c|}
\hline & $f$ & $\%$ & \%cumulative \\
\hline \multicolumn{4}{|c|}{ Gender } \\
\hline Male & 221 & 45,5 & 45,5 \\
\hline Female & 265 & 54,5 & 100 \\
\hline Total & 486 & 100 & 100 \\
\hline \multicolumn{4}{|c|}{ Age } \\
\hline $20-30$ & 209 & 43,0 & 43 \\
\hline $31-40$ & 232 & 47,7 & 90,7 \\
\hline $41-50$ & 37 & 7,6 & 98,3 \\
\hline 51 and above & 8 & 1,6 & 100 \\
\hline Total & 486 & 100 & 100 \\
\hline \multicolumn{4}{|c|}{ Graduation Grade } \\
\hline Vocational School & 12 & 2,5 & 2,5 \\
\hline Bachelor's degree & 448 & 92,2 & 94,7 \\
\hline Master's degree & 26 & 5,3 & 100 \\
\hline Total & 486 & 100 & 100 \\
\hline \multicolumn{4}{|c|}{ Period of Service } \\
\hline Less than 1 year & 48 & 9,9 & 9,9 \\
\hline $1-5$ years & 97 & 20 & 29,9 \\
\hline $6-10$ years & 151 & 31,1 & 61,0 \\
\hline $11-15$ years & 147 & 30,2 & 90,2 \\
\hline 16 years or more & 43 & 8,8 & 100 \\
\hline Total & 386 & 100 & 100 \\
\hline
\end{tabular}

According to Table 1 , almost $55 \%$ and $45 \%$ of the teachers in the selected sample group are male and female respectively. As for age group, $43 \%$ is in $20-30$ age group, $48 \%$ is in $31-40$ age group, $8 \%$ is in $41-50$ age group and approximately $2 \%$ of the sample group is aged 51 and above. $3 \%$ is formed by vocational school graduates, $92 \%$ is by holders of bachelors and $5 \%$ is by holders of master's degree. $10 \%$ of the sample group has a period of service of less than 1 year, \% $201-5$ years, 31\% 6-10 years, 30\% $11-15$ years and $9 \% 16$ years or more.

Table 2. Values as to the Questions devoted to Personal Tendency Sub-dimension of Primary School Teachers' Tendency to Become Manager

\begin{tabular}{|c|c|c|c|}
\hline 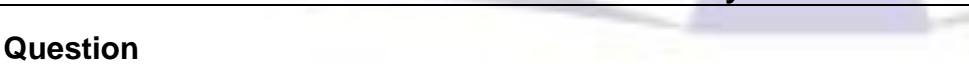 & $N$ & $\overline{\mathrm{X}}$ & SS \\
\hline Being manager is not my pair of shoes. & 486 & 3,14 & 1,395 \\
\hline I believe that being manager is a reputable mission. & 486 & 3,78 & 1,041 \\
\hline $\begin{array}{l}\text { If I were a manager, I could create a better job environment by } \\
\text { positively affecting my work fellows. }\end{array}$ & 486 & 3,73 & ,965 \\
\hline I am trying to improve myself as I am planning to become manager. & 486 & 2,58 & 1,202 \\
\hline $\begin{array}{l}\text { I believe that finding pretexts to stay away from management comes } \\
\text { to mean leaving the square to talentless people }\end{array}$ & 486 & 3,35 & 1,285 \\
\hline Being manager is not a satisfactory promotion for me. & 486 & 2,29 & 1,150 \\
\hline l'd rather manage than be managed. & 486 & 3,28 & 1,229 \\
\hline $\begin{array}{l}\text { I think that managing adults would generate more job satisfaction } \\
\text { than managing children and young people. }\end{array}$ & 486 & 3,06 & 1,194 \\
\hline $\begin{array}{l}\text { I find being a manager pleasurable since it requires being versatile } \\
\text { and active. }\end{array}$ & 486 & 3,06 & 1,234 \\
\hline Mean & & 3,14 & 1,18 \\
\hline
\end{tabular}


$N$ : Number of samples

$\overline{\mathrm{X}}$ : Sample mean

ss : Standard error

According to Table 2, personal tendency sub-dimension of teachers' tendency to become manager varies around $I$ am indecisive with the arithmetic mean value of $\overline{\mathrm{X}}=3,14$. Standard error is 1,18 on average. This value indicates the proximity degree of sample statistics to the universe parameter. When the data is examined, it is observed that the expression I believe that being manager is a reputable mission has the highest value with an arithmetic mean of $\bar{X}=3,78$. This can be attributed to managers' positive impression on teachers. This tendency may be caused by managers holding higher office and being entrusted with wider authorities. It is also observed that the expression Being manager is not a satisfactory promotion for me has the lowest value with an arithmetic mean of $\bar{X}=2,29$. This can be explained by the fact that there is no difference between managers and teachers in terms of personal rights, as caused by the fact that managers are working full-day while teachers are working half-day.

Table 3. Values as to the Questions devoted to General Tendency Sub-dimension of Primary School Teachers' Tendency to Become Manager

\begin{tabular}{|c|c|c|c|}
\hline Question & $N$ & $\overline{\mathrm{X}}$ & SS \\
\hline Being manager is a stressful mission. & 486 & 2,11 & 1,083 \\
\hline $\begin{array}{l}\text { If manager was determined by election, my work-fellows would elect } \\
\text { me. }\end{array}$ & 486 & 3,08 & 1,062 \\
\hline $\begin{array}{l}\text { It is not a good thing for a teacher to leave classroom to become } \\
\text { manager. }\end{array}$ & 486 & 2,61 & 1,355 \\
\hline I believe that my skills fit for being manager. & 486 & 3,49 & 1,150 \\
\hline Managers' salary is not worth suffering trouble. & 486 & 2,37 & 1,248 \\
\hline Working hours of managers are too long. & 486 & 2,47 & 1,235 \\
\hline $\begin{array}{l}\text { There is no management school; one cannot become manager but be } \\
\text { born as manager. }\end{array}$ & 486 & 2,98 & 1,380 \\
\hline Profession of teacher is preferred because it is a half-day job. & 486 & 2,85 & 1,425 \\
\hline It is difficult for managers to supervise and evaluate teachers. & 486 & 3,04 & 1,152 \\
\hline $\begin{array}{l}\text { Being manager is something like housework. Its value is appreciated } \\
\text { only when it is not performed. }\end{array}$ & 486 & 3,38 & 1,172 \\
\hline $\begin{array}{l}\text { A teacher who becomes manager accepts to sacrifice holidays and off } \\
\text { days. }\end{array}$ & 486 & 2,53 & 1,296 \\
\hline Mean & & 2,81 & 1,23 \\
\hline
\end{tabular}

According to Table 3, general tendency sub-dimension of teachers' tendency to become manager varies around I do not agree with the arithmetic mean value of $\bar{X}=2,81$. Standard error, which reflects the proximity degree of sample statistics to the universe parameter, was calculated as 1,23 . It is observed that the expression I believe that my skills fit for being manager has the highest value with an arithmetic mean of $\overline{\mathrm{X}}=3,49$. In the light of this value, it can be argued that teachers are self-confident in being manager. On the other hand, the expression Being manager is a stressful mission has the lowest value with an arithmetic mean of $\bar{X}=2,11$, which indicates that teachers do not regard being a manager as a stressful mission.

Table 4. Results of Kruskal Wallis-H Test - Primary School Teachers' Tendency to Become Manager vs Age Variable

\begin{tabular}{|c|c|c|c|c|c|c|}
\hline Score & Groups & $N$ & $\overline{\mathrm{X}}$ line & $x^{2}$ & s.d & $p$ \\
\hline \multirow{5}{*}{$\begin{array}{l}\text { Tendency to } \\
\text { become manager }\end{array}$} & $20-30$ & 209 & 2,38 & \multirow{5}{*}{, 52} & \multirow{5}{*}{6} & \multirow{5}{*}{,915 } \\
\hline & $31-40$ & 232 & 2,46 & & & \\
\hline & $41-50$ & 37 & 2,48 & & & \\
\hline & 51 and above & 8 & 2,61 & & & \\
\hline & Total & 486 & & & & \\
\hline \multirow{5}{*}{ Personal tendency } & $20-30$ & 209 & 2,47 & \multirow{5}{*}{, 58} & \multirow{5}{*}{6} & \multirow{5}{*}{,901 } \\
\hline & $31-40$ & 232 & 2,39 & & & \\
\hline & $41-50$ & 37 & 2,44 & & & \\
\hline & 51 and above & 8 & 2,64 & & & \\
\hline & Total & 486 & & & & \\
\hline \multirow{5}{*}{ General tendency } & $20-30$ & 209 & 2,29 & \multirow{5}{*}{3,68} & \multirow{5}{*}{6} & \multirow{5}{*}{,299 } \\
\hline & $31-40$ & 232 & 2,54 & & & \\
\hline & $41-50$ & 37 & 2,53 & & & \\
\hline & 51 and above & 8 & 2,38 & & & \\
\hline & Total & 486 & & & & \\
\hline
\end{tabular}


$x^{2}$ : Critical value

s.d : Degree of freedom

$p$ : Probability value

$\mathrm{H}_{\mathrm{o}}$ : There is no differentiation in primary school teachers' tendency to become manager against age variable.

$\mathrm{H}_{\mathrm{A}}$ : There is a differentiation in primary school teachers' tendency to become manager against age variable.

In the Table 4 where impact of age variable on tendency to become manager is analyzed:

When $\left[x^{2}\right.$ calculated $]<\left[x^{2}\right.$ table $]([0,52]<[18,54]) H_{0}$ is not rejected; i.e., there is no differentiation. In addition, the results obtained are significant as $p$ value is $0,015<0,05$. As the personal tendency does not differ by age $[(0,58)<(18,54)] H_{0}$ is not rejected and as $p$ value is $0,901>0,05$, no significant differentiation is observed. The same assessments apply to general tendency. There is no significant differentiation ( $x^{2}$ table s. $\left.d 6 ; \alpha=0,05\right)$.

Table 5. Results of Kruskal Wallis-H Test - Primary School Teachers' Tendency to Become Manager vs Graduation Grade

\begin{tabular}{|c|c|c|c|c|c|c|}
\hline Score & Groups & $N$ & $\overline{\mathrm{x}}$ line & $x^{2}$ & s.d & $p$ \\
\hline \multirow{4}{*}{$\begin{array}{c}\text { Tendency to } \\
\text { become manager }\end{array}$} & Vocational School & 12 & 2,50 & \multirow{4}{*}{1,27} & \multirow{4}{*}{2} & \multirow{4}{*}{, 529} \\
\hline & Bachelor & 448 & 2,41 & & & \\
\hline & Master & 26 & 2,73 & & & \\
\hline & Total & 486 & & & & \\
\hline \multirow{4}{*}{ Personal tendency } & Vocational School & 12 & 2,46 & \multirow{4}{*}{1,33} & \multirow{4}{*}{2} & \multirow{4}{*}{, 514} \\
\hline & Bachelor & 448 & 2,41 & & & \\
\hline & Master & 26 & 2,74 & & & \\
\hline & Total & 486 & & & & \\
\hline \multirow{4}{*}{ General tendency } & Vocational School & 12 & 2,59 & \multirow{4}{*}{1,36} & \multirow{4}{*}{2} & \multirow{4}{*}{, 596} \\
\hline & Bachelor & 448 & 2,41 & & & \\
\hline & Master & 26 & 2,68 & & & \\
\hline & Total & 486 & & & & \\
\hline
\end{tabular}

$\mathrm{H}_{\mathrm{o}}$ : There is no differentiation in primary school teachers' tendency to become manager against graduation grade.

$\mathrm{H}_{\mathrm{A}}$ : There is a differentiation in primary school teachers' tendency to become manager against graduation grade.

In Table 5, which includes the values measuring whether or not there is any differentiation in primary school teachers' tendency to become manager due to graduation grade: since, $\left[x^{2}\right.$ calculated $]<\left[x^{2}\right.$ table] in general, $H_{0}$ is not rejected, probability value, $p>0,05$ and there is no significant differentiation. 
Table 6. Result of One-Way Analysis of Variance - Primary School Teachers' Tendency to Become Manager vs Period of Service

\begin{tabular}{|c|c|c|c|c|c|c|c|c|c|c|}
\hline \multicolumn{5}{|c|}{$N, \overline{\mathrm{X}}$ and $s s$ values } & \multicolumn{6}{|c|}{ ANOVA results } \\
\hline Score & Group & $N$ & $\overline{\mathrm{X}}$ & ss & Var.K. & $K T$ & s.d & $K O$ & $F$ & $p$ \\
\hline \multirow{6}{*}{$\begin{array}{c}\text { Tendency } \\
\text { to become } \\
\text { manager }\end{array}$} & $\begin{array}{l}\text { Less than } \\
1 \text { year }\end{array}$ & 48 & 2,96 & 7,82 & $\begin{array}{l}\text { Inter- } \\
\text { group }\end{array}$ & 271,50 & 4 & 67,88 & \multirow{6}{*}{,856 } & \multirow{6}{*}{,490 } \\
\hline & $1-5$ years & 97 & 2,98 & 9,63 & & & & & & \\
\hline & $6-10$ years & 151 & 2,92 & 8,60 & & & & & & \\
\hline & $\begin{array}{l}11-15 \\
\text { years }\end{array}$ & 147 & 2,94 & 8,59 & In-group & 38130,57 & 381 & 79,27 & & \\
\hline & $\begin{array}{l}16 \text { years or } \\
\text { more }\end{array}$ & 43 & 3,05 & 10,36 & Total & 38402,07 & 385 & & & \\
\hline & Total & 486 & 2,95 & 8,90 & & & & & & \\
\hline \multirow{6}{*}{$\begin{array}{l}\text { Personal } \\
\text { tendency }\end{array}$} & $\begin{array}{l}\text { Less than } \\
1 \text { year }\end{array}$ & 48 & 3,19 & 4,868 & $\begin{array}{l}\text { Inter- } \\
\text { group }\end{array}$ & 339,18 & 4 & 84,80 & \multirow{6}{*}{2,361} & \multirow{6}{*}{,052 } \\
\hline & $1-5$ years & 97 & 3,29 & 6,104 & & & & & & \\
\hline & $6-10$ years & 151 & 3,02 & 5,731 & & & & & & \\
\hline & $\begin{array}{l}11-15 \\
\text { years }\end{array}$ & 147 & 3,08 & 6,316 & In-group & 17275,87 & 381 & 35,92 & & \\
\hline & $\begin{array}{l}16 \text { years or } \\
\text { more }\end{array}$ & 43 & 3,21 & 6,607 & Total & 17615,05 & 385 & & & \\
\hline & Total & 486 & 3,14 & 6,027 & & & & & & \\
\hline \multirow{6}{*}{$\begin{array}{l}\text { General } \\
\text { tendency }\end{array}$} & $\begin{array}{l}\text { Less than } \\
1 \text { year }\end{array}$ & 48 & 2,78 & 4,657 & $\begin{array}{l}\text { Inter- } \\
\text { group }\end{array}$ & 143,02 & 4 & 35,77 & \multirow{5}{*}{1,625} & \multirow{5}{*}{,167 } \\
\hline & $1-5$ years & 97 & 2,73 & 4,816 & & & & & & \\
\hline & $6-10$ years & 151 & 2,82 & 4,681 & & & & & & \\
\hline & $\begin{array}{l}11-15 \\
\text { years }\end{array}$ & 147 & 2,82 & 4,329 & In-group & 10586,62 & 381 & 22,01 & & \\
\hline & $\begin{array}{l}16 \text { years or } \\
\text { more }\end{array}$ & 43 & 2,92 & 5,603 & Total & 10729,65 & 385 & & & \\
\hline & Total & 486 & 2,81 & 4,704 & 2 & & & & & \\
\hline
\end{tabular}

F : Critical value

$\mathrm{H}_{0}$ : There is no differentiation in primary school teachers' tendency to become manager against period of service.

$\mathrm{H}_{\mathrm{A}}$ : There is a differentiation in primary school teachers' tendency to become manager against period of service.

In Table 6, which includes the values measuring whether or not there is any differentiation in primary school teachers' tendency to become manager due to period of service; as there is no differentiation between tendency to become manager and both personal and general tendency $[F$ calculated $]<[F$ table $] H_{\circ}$ is not rejected and as $p>0,05$, there is no significant differentiation (In F table, the corresponding value for $\alpha=0,05$ is observed to be 9,55 ). In other words, there is no differentiation in tendency to become manager arising out of period of service. 
Table 7. Results of Independent Group t Test - Primary School Teachers' Tendency to Become Manager vs Personal Tendency and General Tendency

\begin{tabular}{|c|c|c|c|c|c|c|c|}
\hline \multirow{2}{*}{ Tendency } & \multirow[b]{2}{*}{ Groups } & \multirow{2}{*}{$N$} & \multirow{2}{*}{$\overline{\mathrm{X}}$} & \multirow{2}{*}{ SS } & \multirow{2}{*}{$\mathrm{Sh}_{\overline{\mathrm{x}}}$} & \multicolumn{2}{|c|}{$\begin{array}{l}\text { Independent Group t } \\
\text { Test Results }\end{array}$} \\
\hline & & & & & & $t$ & $p$ \\
\hline \multirow{2}{*}{$\begin{array}{l}\text { Tendency to } \\
\text { become manager }\end{array}$} & Male & 265 & 2,98 & 9,11 & ,56 & \multirow{2}{*}{$-1,46$} & \multirow{2}{*}{,146 } \\
\hline & Female & 221 & 2,92 & 8,61 & ,58 & & \\
\hline \multirow{2}{*}{$\begin{array}{l}\text { Personal } \\
\text { tendency }\end{array}$} & Male & 265 & 3,2 & 6,33 & 0,39 & \multirow{2}{*}{$-2,23$} & \multirow{2}{*}{0,026} \\
\hline & Female & 221 & 3,06 & 5,59 & 0,38 & & \\
\hline \multirow{2}{*}{ General tendency } & Male & 265 & 2,8 & 4,65 & 0,29 & \multirow{2}{*}{0,95} & \multirow{2}{*}{0,924} \\
\hline & Female & 221 & 2,81 & 4,78 & 0,32 & & \\
\hline
\end{tabular}

$\mathrm{Sh}_{\overline{\mathrm{x}}}:$ Standard error

$\boldsymbol{t}$ : Critical value

$\mathrm{H}_{0}$ : There is no differentiation in primary school teachers' tendency to become manager against gender.

$\mathrm{H}_{\mathrm{A}}$ : There is a differentiation in primary school teachers' tendency to become manager against gender.

According to Table 7, which indicates whether or not there is a differentiation in primary school teachers' tendency to become manager due to gender differentiation, if [t calculated] $>$ [t table], then $H_{0}$ is rejected. As $[(1,46)<(1,96)] H_{0}$ is not rejected; i.e., there is no differentiation. Moreover, as $p$ (probability) value does not satisfy the condition $0,146>0,05$ ( $p<$ $0,05)$, no significant difference was observed ( $t$ table \%95=1,96; $p=0,05$ ).

In the personal tendency sub-dimension of primary school teachers' tendency to become manager, since [ $t$ calculated] $(2,23)>$ [t table] $(1,96), H_{0}$ is rejected; i.e., personal tendency affects whether or not to become manager. In addition, significant differentiation was identified because $p$ value is $0,026<0,05$.

It is considered that general tendency sub-dimension of primary school teachers' tendency to become manager does not affect whether or not to become manager on account of the fact that [t calculated] $<$ [t table] $0,95<1,96$ and $p>0,05$; i.e., there is no differentiation.

\section{CONCLUSION}

In the scope of this study, which is a qualitative research in nature, it was endeavored to analyze the teachers' tendency to become manager by using scale for primary school teachers' tendency to become manager and taking into account the following criteria: age, gender, period of service, graduation grade. Survey was conducted to 486 primary school teachers and Likert scale was employed. $45 \%$ and $55 \%$ of the participants are male and female, respectively. $48 \%$ of the participants falls within 31-40 age group, 93\% consists of bachelors and period of service ranges between 6 and 10 years.

According to study, in which primary school teachers' tendency to become manager is handled under two subdimensions; i.e., personal tendency and general tendency, age, gender, graduation grade and period of service have no impact on primary school teachers' tendency to become manager. However, it is observed that gender puts an impact on the tendency to become manager according to independent group t test results. Male primary school teachers' tendency to become manager is greater than female teachers. As compared to the teachers working at other educational stages, primary school teachers work half-day. On the other hand, managerial positions require full-day work. This difference in working hours may be responsible for the low level of personal tendency shown by female primary school teachers.

General tendency to become manager is observed to be flower than personal tendency, which suggests that the teachers who have personal tendency to become manager lose their tendency in general terms. In the current educational management system in Turkey, primary school management is not regarded as a profession. Nevertheless, teachers consider being primary school manager as a progression in their career. Assigning a good teacher to managerial positions may occasionally bring about some challenges: If someone whose personality structure and individual preferences do not fit for managerial positions becomes a manager, he/she may not be beneficial to the school, and the school may a valuable teacher. For these reasons, personality characteristics of a teacher who intends to become primary school manager must be analyzed in depth.

\section{REFERENCES}

Aksu, M.B. (2004). İlköğretim okulu öğretmenlerinin yöneticilik eğilimleri: Malatya ili örneği. XII. Eğitim Bilimleri Kongresi Bildirileri, Gazi Üniversitesi Eğitim Bilimleri Enstitüsü, 1, 709-727.

Aslan, M.H. (2011). Türkiye'de yükseköğretimin finansmanında yol ayrımı: Etkin, adil ve cesur adımlar. Uluslar arası Yükseköğretim Kongresi, 2, 1170-1182. 
Balcı, A. (2009). Sosyal bilimlerde araştırma (7. Baskı). Ankara: Pegem Akademi Yayınları.

Balcı, A. (2010). Açıklamalı eğitim yönetimi terimleri sözlüğü (2. Baskı). Ankara: Pegem Akademi Yayınları.

Bingül, M. ve Hacıfazlıoğlu, Ö. (2011). Sınıf öğretmenlerinin yönetici olma eğilimleri: İstanbul Esenyurt ilçesi örneği. Uluslararası İnsan Bilimleri Dergisi, 8 (1), 860-881.

Bursalıoğlu, Z. (2011). Okul yönetiminde yeni yapı ve davranış (16. Baskı). Ankara: Pegem Akademi Yayınları.

Çelikten, M. (2004). Okul müdürü koltuğundaki kadınlar: Kayseri ili örneği. Sosyal Bilimler Enstitüsü Dergisi, 17, $91-118$.

Dura, C. (1996). Eğitim ve ekonomi ilişkileri. Erciyes Üniversitesi Sosyal Bilimler Enstitüsü Dergisi, 7, 19-47.

Erdoğan, İ. (2010). Eğitim ve okul yönetimi (8. Baskı). İstanbul: Alfa Yayınları.

Gölpek, F. (2013). Private costs in finance of higher education: Sample of Gaziantep province. International Journal of Business and Social Science 4(13), 154-168.

Gölpek, F. (2012). Yükseköğretim finansmanında ertelenmiş maliyete katılma yöntemi: Öğrenci kredileri. Uluslar arası Yükseköğretim Kongresi, 2, 1219-1226.

Gölpek, F. (2011). Türkiye'de adalet ilkesi bakımından yükseköğretimde finansman politikası: Kim faydalanıyor? Kim ödüyor? Anadolu Üniversitesi Sosyal Bilimler Dergisi, 11(3), 149-176.

Gürsel, M. (2003). Okul yönetimi. Konya: Eğitim Kitabevi.

Kaptan, S. (1995). Bilimsel araştırma ve istatistik teknikleri. (10. Baskı). Ankara: Tekışık Yayınları.

Karasar, N. (1994). Bilimsel araştırma yöntemi: kavramlar, ilkeler, teknikler (6.Baskı). Ankara: 3A Araştırma Eğitim Danışmanlık Ltd.

Keskinkılıç, K. (2011). Yönetim ve okul yönetimi ile ilgili temel kavramlar. K. Keskinkılıç (Ed.), Türk eğitim sistemi ve okul yönetimi (ss. 1-28). Ankara: Pegem Akademi Yayınları.

Ministry of National Education (MEB-2009). Milli eğitim temel kanunu. http://mevzuat.meb.gov.tr.

Ministry of National Education (MEB-2013). İlköğretim ve eğitim kanunu. http://mevzuat.meb.gov.tr.

Ministry of National Education (MEB-2012). Milli eğitim istatistikleri-örgün eğitim. http://mevzuat.meb.gov.tr.

Narman, G. (2004). Kadının iş yaşamına katılımı ve kadın yöneticilik modelleri. Ankara Üniversitesi, Sosyal Bilimler Enstitüsü Dergisi, 17, 91-118.

OECD (2013). Education at a glance. http://www.oecd.org/

Şimşek, N. (2010). Kadın öğretmenlerin yönetici olmalarını engelleyen önyargı ve diğer faktörlerin incelenmesi. Yayınlanmamış yüksek lisans tezi. Yeditepe Üniversitesi. İstanbul.

Şişman, M. (2011). Eğitimde mükemmellik arayışı etkili okullar (2. Baskı). Ankara: Pegem Akademi Yayınları.

Taymaz, A.H. (2011). Okul yönetimi (10. Baskı). Ankara: Pegem Akademi Yayınları. 